\title{
Early Start Of Tenofovir Treatment Achieves Better Viral Suppression In Pregnant Women With A High HBV Viral Load: A Real-World Prospective Study
}

This article was published in the following Dove Press journal:

Infection and Drug Resistance

\author{
Fan Gao (iD) \\ Wen-Tao Zhang ${ }^{2}$ \\ Ya-Yun Lin (D) ${ }^{2}$ \\ Wei-Min Wang ${ }^{2}$ \\ $\mathrm{Na} X \mathrm{u}^{2}$ \\ Gui-Qin Bai (iD) ${ }^{2}$ \\ 'Clinical Research Center, The First \\ Affiliated Hospital of Xi'an Jiaotong \\ University, Xi'an, Shaanxi 71006I, \\ People's Republic of China; ${ }^{2}$ Department \\ of Gynecology and Obstetrics, The First \\ Affiliated Hospital of Xi'an Jiaotong \\ University, Xi'an, Shaanxi 71006I, \\ People's Republic of China
}

Correspondence: Gui-Qin Bai Department of Gynecology and Obstetrics, The First Affiliated Hospital of Xi'an Jiaotong University, 277 Yanta West Road, Xi'an, Shaanxi 7I006I, People's Republic of China

Tel +86-18991232517

Email baigq@I26.com
Purpose: To investigate whether tenofovir disoproxil fumarate (TDF) treatment that started from the second trimester had an advantage over TDF treatment that started from the third trimester.

Patients and methods: Twenty 35-year-old pregnant women with hepatitis B virus (HBV) DNA $>2 \times 106 \mathrm{IU} / \mathrm{mL}$ were prospectively enrolled in this study. All participants were divided into two subgroups: the second trimester group who started TDF treatment at 24-27 weeks and the third trimester group who started TDF treatment at 28-30 weeks. The primary outcome was the change in serum HBV DNA level from baseline to delivery. Each parameter was tested every 4 weeks from TDF initiation to 3 months postpartum.

Results: There were 80 pregnant women in the second trimester group and 49 pregnant women in the third trimester group. The decline in HBV DNA from baseline to delivery was more obvious in the second trimester group $(4.8 \pm 1.2 \log 10 \mathrm{IU} / \mathrm{mL})$ than that in the third trimester group $(4.3 \pm 1.1 \log 10 \mathrm{IU} / \mathrm{mL}, \mathrm{p}=0.041)$. The downward shift of haemoglobin $(\mathrm{HB})$ from baseline to delivery was greater in the second trimester group $(10.6 \pm 10.7 \mathrm{~g} / \mathrm{L})$ than in the third trimester group $(6.3 \pm 12.3 \mathrm{~g} / \mathrm{L}, \mathrm{p}=0.041)$. The decline in HBV DNA from baseline to delivery was linearly related to the start of TDF treatment from the second trimester $(\beta=0.50$ and $95 \% \mathrm{CI}: 0.26-0.75, \mathrm{p}<0.001)$. There were no significant differences between the two groups regarding HBV serologic markers and safety indicators.

Conclusion: Starting TDF treatment from the second trimester achieved better viral suppression than starting TDF treatment from the third trimester in highly viraemic pregnant women without increasing additional adverse reactions. HB level needed frequent monitoring during treatment to avoid anaemia.

Registry number: Clinical Trial No. NCT02719808.

Keywords: tenofovir disoproxil fumarate, efficacy, safety, second trimester, third trimester

\section{Introduction}

Mother-to-child transmission (MTCT) is a dominant risk factor for developing chronic hepatitis B virus (HBV) infection. ${ }^{1-9}$ Prevention of perinatal transmission of HBV infection is still a public health concern globally. ${ }^{10-14}$ Tenofovir disoproxil fumarate (TDF), a nucleotide analogue and potent inhibitor of HBV polymerase, ${ }^{13,15}$ is recommended as the preferred antiviral treatment for HBV for MTCT prevention. Its high efficiency in viral load reduction, high safety, and low rate of resistant 
mutations are well appreciated in several major global guidelines. $^{7,11,13,16-20}$ A previous random control trial (RCT) was conducted to determine the efficacy and safety of TDF therapy in mothers with a high level of HBV DNA by Pan et al The investigators discovered that the rate of MTCT is significantly lower in mothers with TDF therapy than those without antiviral therapy. ${ }^{21}$ This is supported by several prior systematic reviews and meta-analyses, which demonstrate that TDF therapy in HBV infected mothers in the second or third trimester could block MTCT with high efficacy. $^{4,11,22}$ In addition, a new prospective single-arm study by Wang et al verified these discoveries of TDF treatment, with a $100 \%$ success rate in preventing MTCT in a real-world setting.

Because of the heterogeneous study designs and different therapeutic strategies, efficacy and safety problems of TDF and the exact time for the initiation of therapy have not been well described and studied. ${ }^{23}$ Furthermore, most of the previous studies started TDF treatment in the third trimester. $^{1,2,5,6,10,11,20,21,24-28}$ However, data regarding the efficacy and safety in mothers whose treatment commenced in the second trimester (24-27 weeks) are sparse. Whether TDF treatment initiated from the second trimester has advantages over TDF treatment starting from the third trimester in highly viraemic pregnant women is not clear. Therefore, this real-world prospective study aimed to compare the efficacy and safety of TDF treatment starting from the second trimester and third trimester.

\section{Materials And Methods \\ Patient Selection And Study Setting}

In this prospective, single-arm, study patients were recruited from the First Affiliated Hospital of Xi'an Jiaotong University between January 2013 and December 2018. Twenty 35-year-old pregnant women with hepatitis B surface antigen (HBsAg) and hepatitis B e antigen (HBeAg) dualpositive HBV infection were enrolled. The following exclusion criteria were applied: $(1)$ a creatinine $(\mathrm{Cr})$ clearance rate $<100 \mathrm{~mL} / \mathrm{min}$, alanine aminotransferase (ALT) $>5$ times the upper limit of normal (ULN), bilirubin $>2 \mathrm{mg} / \mathrm{dL}$ or evidence of hepatocellular carcinoma, renal dysfunction, or hepatic dysfunction; (2) co-infection with HIV, hepatitis C virus, or hepatitis D virus; (3) a HBV treatment history within 6 months; (4) an abortion history or clinical manifestation of an inevitable abortion; (5) congenital foetal deformity; (6) haemoglobin $(\mathrm{HB})<8 \mathrm{~g} / 100 \mathrm{~mL}$, neutrophils $<1000 / \mathrm{mm}^{3}$, or albumin $<2.5 \mathrm{~g} / 100 \mathrm{~mL}$; (7) special medicine treatment required during the pregnancy; (8) the biological father of the infant has chronic HBV infection; (9) serum HBV DNA titre $<2 \times 10^{6}(6.3 \log 10) \mathrm{IU} / \mathrm{mL}$; (10) did not receive TDF treatment. This study was approved by the Ethics Committee of the First Affiliated Hospital of Xi'an Jiaotong University and registered in Clinical Trial (registration number: NCT02719808). All patients signed the written consent form and all protocols conformed to the standards of the Declaration of Helsinki.

\section{Study Procedures And Data Collections}

All participants were started on an oral dose of $300 \mathrm{mg} /$ day of TDF (GSK, China) from the second trimester or third trimester until 1 month postpartum. Antiviral treatment was in accordance with the guidelines and regulations for the prevention of vertical transmission of HBV in pregnancy (Chinese Medical Association-Society of Obstetrics and Gynecology, 2013). Mothers were followed up every 4 weeks from the initiation of TDF to 3 months postpartum by patient visits to the outpatient clinic. Mothers' $\mathrm{HBV}$ DNA, HBV serologic markers, aspartate aminotransferase (AST), ALT, serum albumin (ALB), HB, blood urea nitrogen (BUN), and $\mathrm{Cr}$ were tested before TDF treatment and continued every visit.

\section{Laboratory Evaluation}

The primary outcome was the change in serum HBV DNA levels of mothers from baseline (before treatment) to delivery. The HBV DNA was tested with the PCR-fluorescence probe method (Daan GENE, China). The secondary efficacy outcomes for mothers were HBsAg, $\mathrm{HBeAg}$, hepatitis $\mathrm{B}$ e antibody ( $\mathrm{HBe} A b)$, and hepatitis $\mathrm{B}$ core antibody $(\mathrm{HBc} A b)$ levels and secondary safety outcomes for mothers were AST, ALT, ALB, HB, BUN, and Cr. A severe ALT flare was defined as a level above 5-10 times the ULN and a serious ALT flare was defined as a level more than 10 times the ULN. ${ }^{21}$

\section{Statistical Analysis}

Study populations were divided into two subgroups: patients who started TDF treatment from the second trimester (24-27 weeks) and patients who started TDF treatment in the third trimester (28-30 weeks). Baseline characteristics and laboratory results are presented as percentages for categorical variables, means \pm standard deviation for normally distributed continuous variables, and medians [interquartile ranges (Q3-Q1)] for non-normally distributed continuous data. HBV DNA level was transformed to a logarithmic scale 
$(\log 10 \mathrm{IU} / \mathrm{mL})$. The changes in each indicator from baseline to delivery and from delivery to 3 months postpartum were compared between the two groups. Pearson $\chi^{2}$ test, modified by Fisher's exact test, was used to compare the two groups for categorical variables. The $t$-test and Mann-Whitney $U$-test for nonparametric analysis were used to compare two groups for continuous variables. A mixed model with repeated measures analysis was used to evaluate the effect of trimester on the change in serum HBV DNA level and other serum parameters during the follow-up period. Age and family history of HBV were adjusted in the model. $p 1$ was calculated to test whether the effect of the group (second trimester vs third trimester) is significant in the mixed linear model. $p 2$ was calculated to test whether the effect of follow-up time is significant in the mixed linear model. Multiple linear regression analysis was used to analyse the relationship between HBV DNA decline (baseline-delivery) and baseline factors, including age, family history of $\mathrm{HBV}$, initiated trimester, $\mathrm{HBV}$ DNA, HBsAg, HBeAg, ALT, HB, caesarean section, education, domicile, number of pregnancies before this delivery, and number of deliveries before this delivery. The regression coefficient and 95\% confidence interval (CI) were depicted. $p<0.05$ was considered significant. All data analyses were conducted with R 3.5.1 and SPSS 24.0 (SPSS, IL, USA).

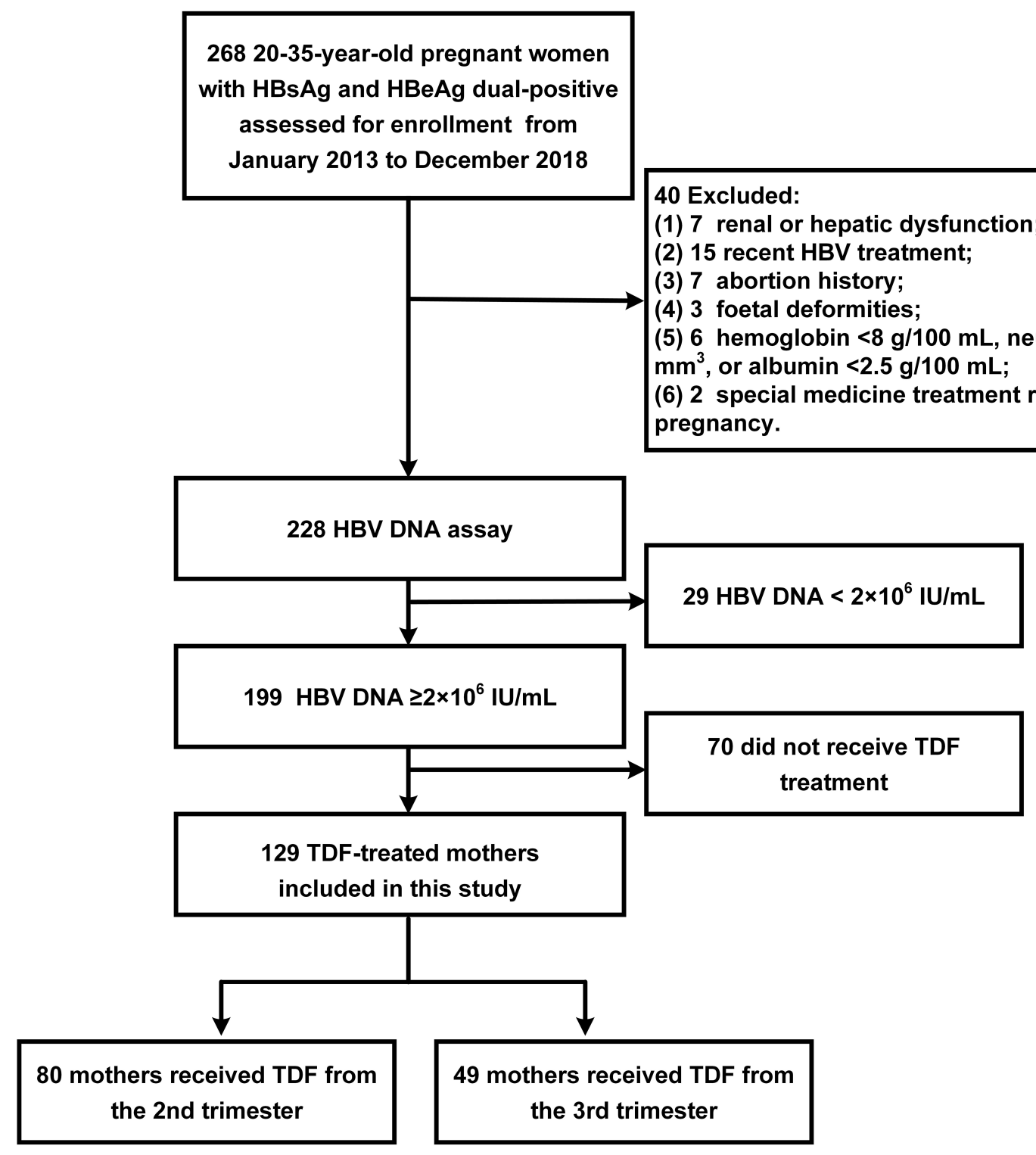

Figure I The screening process of study population.

Abbreviations: $\mathrm{HBsAg}$, hepatitis B surface antigen; $\mathrm{HBeAg}$, hepatitis Be antigen; HBV, hepatitis B virus; DNA, deoxyribonucleic acid; TDF, tenofovir disoproxil fumarate. 


\section{Results}

\section{Study Population}

Among 268 pregnant women that were screened, 129 were included in the final study. Patients who had renal or hepatic dysfunction $(n=7)$, recent $\mathrm{HBV}$ treatment $(n=15)$, abortion history $(n=7)$, foetal deformities $(n=3), H B<8 \mathrm{~g} / 100 \mathrm{~mL}$, neutrophils $<1000 / \mathrm{mm}^{3}$, albumin $<2.5 \mathrm{~g} / 100 \mathrm{~mL}$ ( $\mathrm{n}=6$ ), special medicine treatment $(n=2)$, HBV DNA $<2 \times 106 \mathrm{IU} / \mathrm{mL}$ $(n=29)$, or did not receive TDF treatment $(n=70)$ were excluded. Among the remaining 129 mothers, there were 80 mothers who received TDF treatment from the second trimester and 49 mothers who received TDF treatment from the third trimester. There were no lost follow-ups from baseline to the final visit 12 weeks post-partum. The screening process of the study population is shown in Figure 1. Maternal and infant baseline characteristics are presented in Table 1. The mothers' mean ages at enrolment were 29.1 \pm 3.6 years and $29.4 \pm 4.3$ years in the second trimester and third trimester groups, respectively. There were 20 mothers $(25 \%)$ in the second trimester group and 6 mothers (12.2\%) in the third trimester group who had a family history of HBV. HBV DNA loads at baseline were $7.7 \pm 1.0 \log 10 \mathrm{IU} / \mathrm{mL}$ and $7.8 \pm 1.0 \log 10 \mathrm{IU} / \mathrm{mL}$ in the second trimester and the third trimester groups, respectively. In infants, the mean weights in the second trimester and the third trimester groups were $3.3 \pm 0.3 \mathrm{~kg}$ and $3.2 \pm 0.4 \mathrm{~kg}$, respectively. The lengths in the two groups were $48.7 \pm 2.1 \mathrm{~cm}$ and $48.6 \pm 1.8 \mathrm{~cm}$, respectively. The HBV infection rates in infants were $0 \%$ in both groups. None of the basic characteristics showed significant differences between the two groups (all $p>0.05$ ), except the number of delivery before this delivery.

\section{Maternal Efficacy And Safety Evaluation}

Results regarding the efficacy and safety parameters in two changes (baseline-delivery and delivery 3 months postpartum) are listed in Table 2. The decline in HBV DNA from baseline to delivery was greater in the second trimester group $(4.8 \pm 1.2 \log 10 \mathrm{IU} / \mathrm{mL})$ than that in the third trimester group $(4.3 \pm 1.1 \log 10 \mathrm{IU} / \mathrm{mL}, \mathrm{p}=0.041)$. HBcAb level increased after delivery $(-0.9 \pm 1.8 \mathrm{~s} / \mathrm{co})$ in the second trimester group, whereas it decreased $(0.1 \pm 1.9 \mathrm{~s} / \mathrm{co}, \mathrm{p}=0.002)$ from delivery to 3 months postpartum in the third trimester group. The shift downward in HB from baseline to delivery was greater in patients who started TDF treatment from the second trimester $(10.6 \pm 10.7 \mathrm{~g} / \mathrm{L})$ than that in patients who started from the third trimester $(6.3 \pm 12.3 \mathrm{~g} / \mathrm{L}, \mathrm{p}=0.041)$. Other changes in efficacy and safety indicators were not significant.
Table I Maternal And Infant Characteristics At Baseline

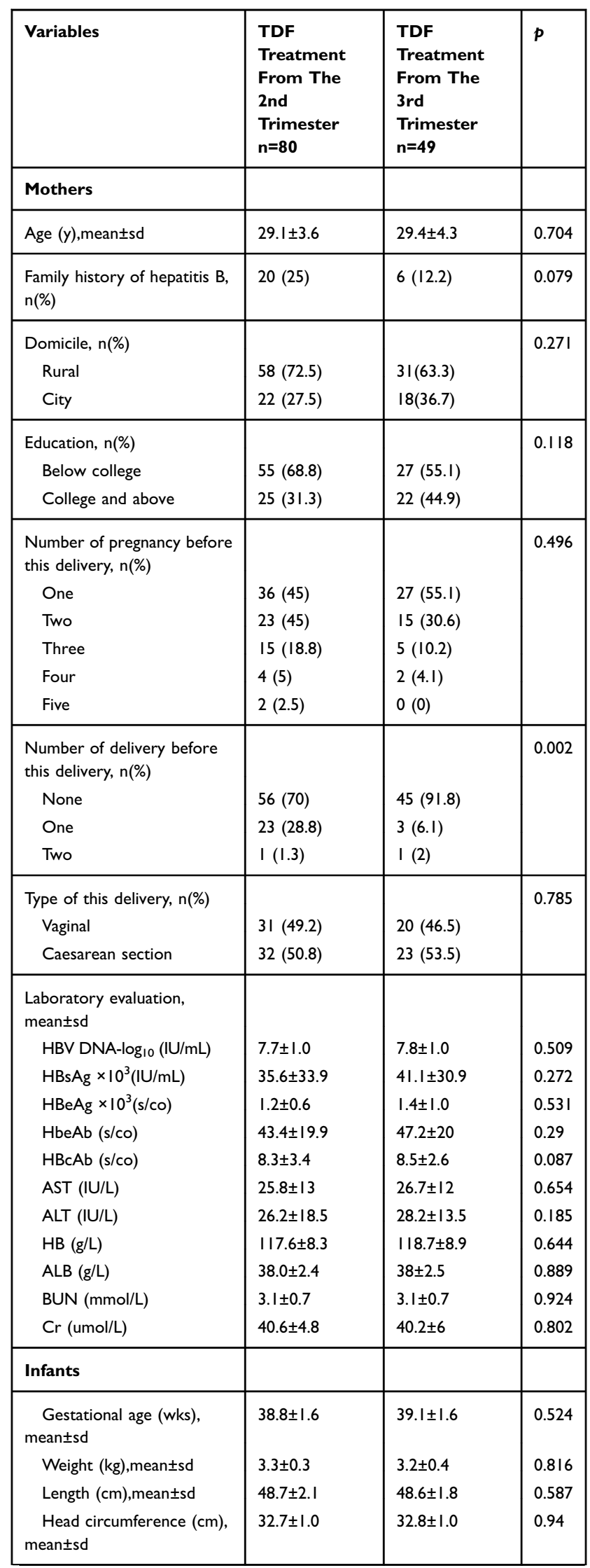

(Continued) 
Table I (Continued).

\begin{tabular}{|c|c|c|c|}
\hline Variables & $\begin{array}{l}\text { TDF } \\
\text { Treatment } \\
\text { From The } \\
\text { 2nd } \\
\text { Trimester } \\
n=80\end{array}$ & $\begin{array}{l}\text { TDF } \\
\text { Treatment } \\
\text { From The } \\
\text { 3rd } \\
\text { Trimester } \\
\text { n=49 }\end{array}$ & $p$ \\
\hline $\begin{array}{l}\text { APGAR score (I min), } \\
\text { mean } \pm s d\end{array}$ & $9.9 \pm 0.3$ & $9.9 \pm 0.4$ & 0.678 \\
\hline $\begin{array}{l}\text { HBV infection at } 7 \text { months } \\
\text { after birth, } n(\%)\end{array}$ & $0(0)$ & $0(0)$ & NA \\
\hline
\end{tabular}

Abbreviations: TDF, tenofovir disoproxil fumarate; HBV-DNA, hepatitis $B$ virus deoxyribonucleic acid; $\mathrm{HBsAg}$, hepatitis $B$ surface antigen; $\mathrm{HBeAg}$, hepatitis $\mathrm{Be}$ antigen; $\mathrm{HBeAb}$, hepatitis $\mathrm{Be}$ antibody; $\mathrm{HBcAb}$, hepatitis $B$ core antibody; AST, aspartate aminotransferase; ALT, alanine aminotransferase; HB, hemoglobin; ALB, albumin; BUN, blood urea nitrogen; $\mathrm{Cr}$, creatinine; NA, not available.

All mothers followed TDF treatment from enrolment to 1 month postpartum without early withdrawal. The alteration process in HBV DNA from baseline before TDF treatment to 3 months postpartum between the two groups is shown in Figure 2. The two groups of patients had a similar variation trend during the whole follow-up period $(\mathrm{p} 1=0.680)$. All mothers' DNA levels were lower than 200,000 IU/mL (5.30 $\log 10 \mathrm{IU} / \mathrm{mL}$ ) at delivery. HBV DNA declined to the lowest point at 1 month postpartum and increased after TDF cessation in both groups ( $2<0.001)$.

The dynamic alterations of $\mathrm{HBsAg}, \mathrm{HBeAg}, \mathrm{HBeAb}$, and $\mathrm{HBcAb}$ were followed from baseline until 3 months postpartum and their variation trends in the two groups are shown in Figure 3. There was no significant difference between the patients in the second trimester and the third trimester group (all p1>0.05) and the two groups had a similar change in HBV serologic markers over time (all p2>0.05).

Dynamic changes in safety parameters for mothers are shown in Figure 4. All of these safety markers showed significant time-varying effects during the follow-up period in the two groups (all p2<0.05). However, there was no significant difference between the two groups (all p1>0.05).

Adverse events between the second trimester and third trimester groups are listed in Table 3 . There were 20 mothers $(25 \%)$ in the second trimester group and 14 mothers $(28.6 \%)$ in the third trimester group who had foetal distress, which had the highest incidence rate among maternal complications. There were 5 mothers $(6.2 \%)$ in the second trimester group and 3 mothers $(6.1 \%)$ in the third trimester group who had an ALT flare. The mean peak ALT values in patients who had an ALT flare were $313.6 \pm 119.0 \mathrm{IU} / \mathrm{L}$ in the second trimester group and $378 \pm 112.6 \mathrm{IU} / \mathrm{L}$ in the third trimester group. There were no
Table 2 Changes Of Effective And Safety Parameters Of Pregnant Women Who Initiated TDF Therapy From The 2nd Trimester And The 3rd Trimester

\begin{tabular}{|c|c|c|c|}
\hline Variables & $\begin{array}{l}\text { TDF } \\
\text { Treatment } \\
\text { From The } \\
\text { 2nd } \\
\text { Trimester } \\
\mathrm{n}=80\end{array}$ & $\begin{array}{l}\text { TDF } \\
\text { Treatment } \\
\text { From } \\
\text { The 3rd } \\
\text { Trimester } \\
\mathrm{n}=49\end{array}$ & $\mathbf{p}$ \\
\hline \multicolumn{4}{|l|}{ HBV DNA-log $10(\mathrm{IU} / \mathrm{mL})$} \\
\hline Baseline-delivery & $4.8 \pm 1.2$ & $4.3 \pm 1.1$ & 0.041 \\
\hline Delivery-3 months postpartum & $-4.5 \pm 1.4$ & $-4.6 \pm 0.9$ & 0.622 \\
\hline \multicolumn{4}{|l|}{$\mathrm{HBsAg} \times 10^{3}(\mathrm{IU} / \mathrm{mL})$} \\
\hline Baseline-delivery & $16.7 \pm 39.8$ & $20.8 \pm 232.2$ & 0.649 \\
\hline Delivery-3 months postpartum & $-33.9 \pm 37.2$ & $-43.5 \pm 48.8$ & 0.726 \\
\hline \multicolumn{4}{|l|}{$\mathrm{HBeAg} \times 10^{3}(\mathrm{~s} / \mathrm{co})$} \\
\hline Baseline-delivery & $0.2 \pm 0.2$ & $0.2 \pm 0.3$ & 0.987 \\
\hline Delivery-3 months postpartum & $-0.3 \pm 0.2$ & $-0.1 \pm 0.2$ & 0.280 \\
\hline \multicolumn{4}{|l|}{ HbeAb (s/co) } \\
\hline Baseline-delivery & $4.8 \pm 16.9$ & $4.5 \pm 16.8$ & 0.926 \\
\hline Delivery-3 months postpartum & $-0.5 \pm 13.2$ & $-2.3 \pm 14.4$ & 0.465 \\
\hline \multicolumn{4}{|l|}{$\mathrm{HBcAb}(\mathrm{s} / \mathrm{co})$} \\
\hline Baseline-delivery & $0.5 \pm 3.2$ & $-0.2 \pm 2.2$ & 0.165 \\
\hline Delivery-3 months postpartum & $-0.9 \pm 1.8$ & $0.1 \pm 1.9$ & 0.002 \\
\hline \multicolumn{4}{|l|}{ AST (IU/L) } \\
\hline Baseline-delivery & $-1.2 \pm 15.3$ & $-1.0 \pm 12.9$ & 0.925 \\
\hline Delivery-3 months postpartum & $-12.8 \pm 40.5$ & $-14.0 \pm 30.3$ & 0.933 \\
\hline \multicolumn{4}{|l|}{ ALT (IU/L) } \\
\hline Baseline-delivery & $0.02 \pm 21.9$ & $-2.0 \pm 31.4$ & 0.674 \\
\hline Delivery-3 months postpartum & $-30.9 \pm 58.3$ & $-32.1 \pm 50.7$ & 0.956 \\
\hline \multicolumn{4}{|l|}{$\mathrm{HB}(\mathrm{g} / \mathrm{L})$} \\
\hline Baseline-delivery & $10.6 \pm 10.7$ & $6.3 \pm 12.3$ & 0.041 \\
\hline Delivery-3 months postpartum & $-15.9 \pm 13.9$ & $-8.4 \pm 15.1$ & 0.179 \\
\hline \multicolumn{4}{|l|}{ ALB $(g / L)$} \\
\hline Baseline-delivery & $I \pm 5.5$ & $0.9 \pm 4.7$ & 0.971 \\
\hline Delivery-3 months postpartum & $-6.0 \pm 4.0$ & $-7.4 \pm 4.4$ & 0.462 \\
\hline \multicolumn{4}{|l|}{ BUN (mmol/L) } \\
\hline Baseline-delivery & $-0.3 \pm 0.3$ & $-0.3 \pm 0.6$ & 0.933 \\
\hline Delivery-3 months postpartum & $-1.0 \pm 1.5$ & $-0.7 \pm 0.7$ & 0.665 \\
\hline \multicolumn{4}{|l|}{$\mathrm{Cr}$ (umol/L) } \\
\hline Baseline-delivery & $-6.9 \pm 9.1$ & $-10.2 \pm 8.0$ & 0.499 \\
\hline Delivery-3 months postpartum & $I \pm 2.3$ & $2.4 \pm 6.2$ & 0.149 \\
\hline
\end{tabular}

Abbreviations: TDF, tenofovir disoproxil fumarate; HBV-DNA, hepatitis $B$ virus deoxyribonucleic acid; $\mathrm{HBsAg}$, hepatitis $B$ surface antigen; $\mathrm{HBeAg}$, hepatitis $\mathrm{Be}$ antigen; $\mathrm{HBeAb}$, hepatitis $\mathrm{Be}$ antibody; $\mathrm{HBcAb}$, hepatitis $\mathrm{B}$ core antibody; AST, aspartate aminotransferase; ALT, alanine aminotransferase; HB, hemoglobin; ALB, albumin; BUN, blood urea nitrogen; $\mathrm{Cr}$, creatinine.

significant differences in adverse events between the two groups. 


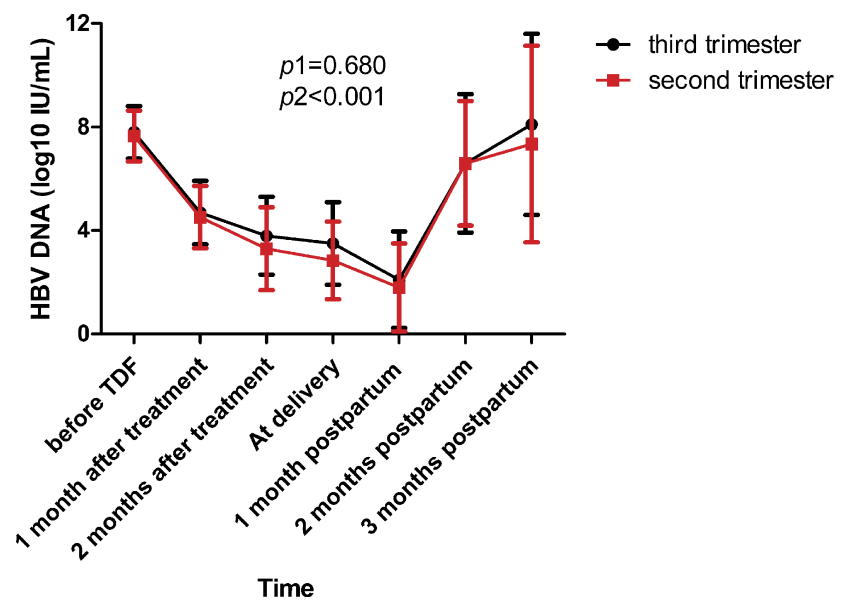

Figure 2 The dynamic changes in the level of HBV DNA.

Notes: pl was calculated to test whether the effect of the group (sencond trimester vs third trimester) is significant in the mixed linear model. p2 was calculated to test whether the effect of follow-up time is significant in the mixed linear model.

\section{Related Factors Of HBV DNA Decline}

Correlation analysis of HBV DNA decline are listed in Table 4. The decline in HBV DNA from baseline to delivery had a positive correlation with starting TDF treatment from the second trimester $(\beta=0.50$ and $95 \%$ CI: $0.26-0.75$, $\mathrm{p}<0.001)$ and HBV DNA level $(\log 10 \mathrm{IU} / \mathrm{mL})$ before treatment $(\beta=0.92$ and $95 \%$ CI: $0.78-1.07, p<0.001)$.

\section{Discussion}

This real-world prospective cohort study compared the efficacy and safety of TDF treatment starting from the second and third trimester. The first main result was that the reduction in viral load was greater in TDF treatment from the second trimester than that in TDF treatment from the third trimester in highly viraemic pregnant women according to the multiple linear regression analysis.
(A)

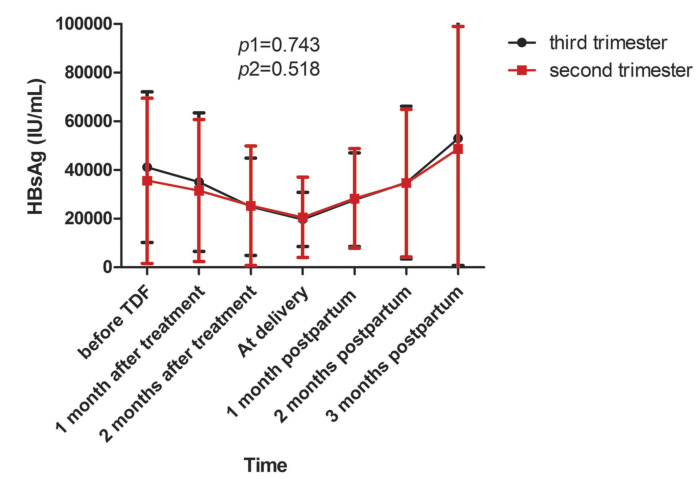

(C)

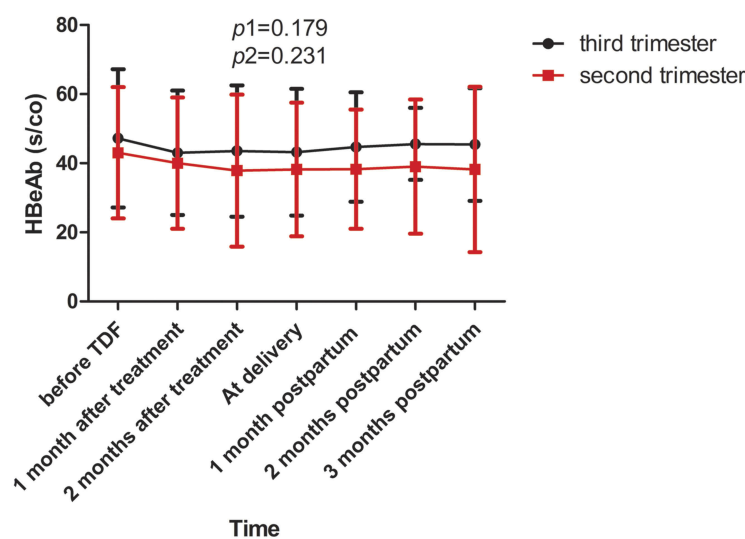

(B)

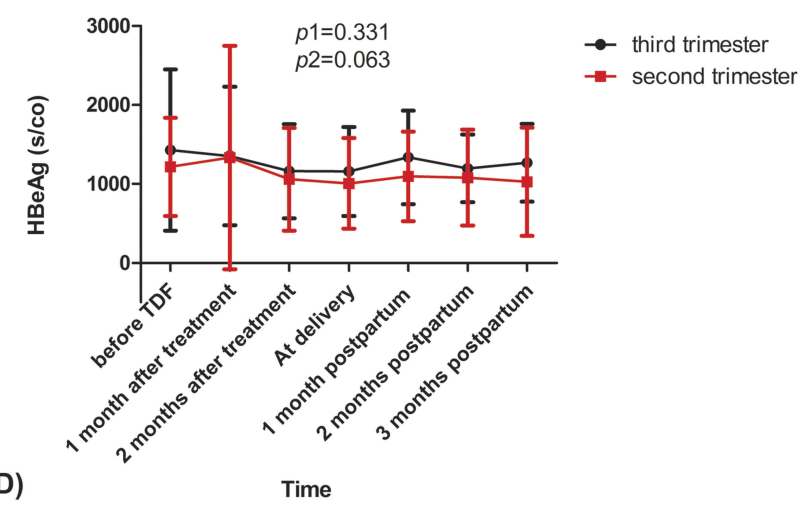

(D)

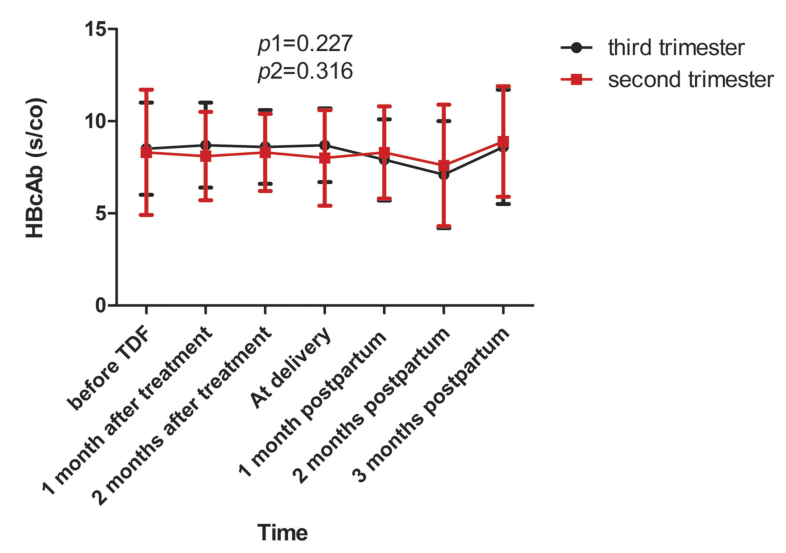

Figure 3 The dynamic changes in the level of $\mathrm{HBsAg}(\mathbf{A}), \mathrm{HBeAg}(\mathbf{B}), \mathrm{HBeAb}(\mathbf{C})$ and $\mathrm{HBcAb}$ (D).

Notes: $p \mid$ was calculated to test whether the effect of the group (sencond trimester vs third trimester) is significant in the mixed linear model. $p 2$ was calculated to test whether the effect of follow-up time is significant in the mixed linear model.

Abbreviations: $\mathrm{HBsAg}$, hepatitis $B$ surface antigen; $\mathrm{HBeAg}$, hepatitis $\mathrm{Be}$ antigen; $\mathrm{HBeAb}$, hepatitis $\mathrm{Be}$ antibody; $\mathrm{HBcAb}$, hepatitis $\mathrm{B}$ core antibody. 
(A)

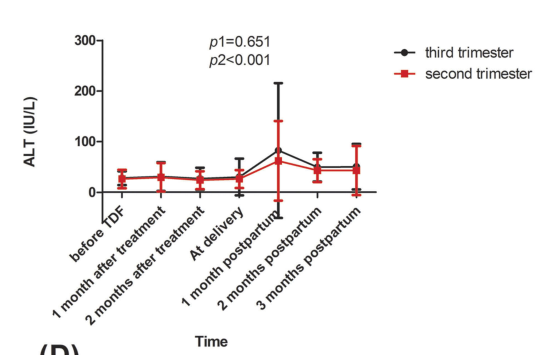

(D)

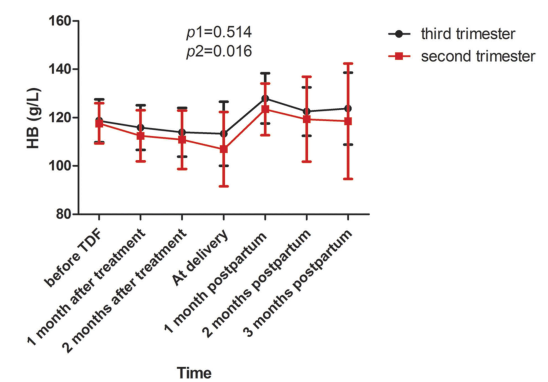

(B)

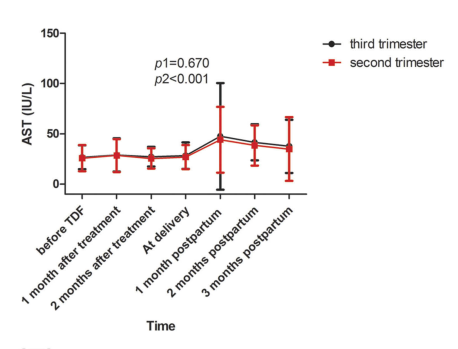

(E)

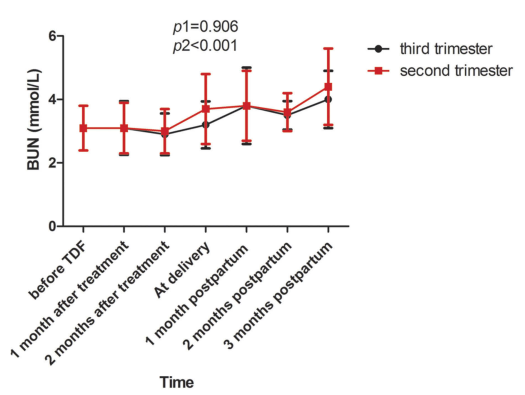

(C)

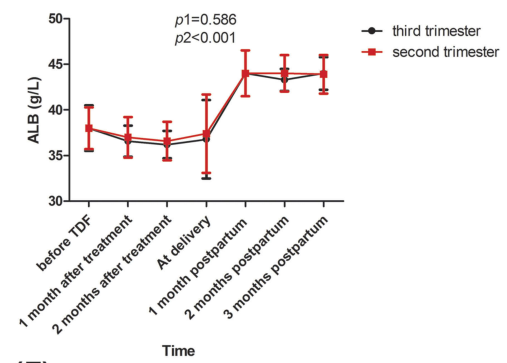

(F)

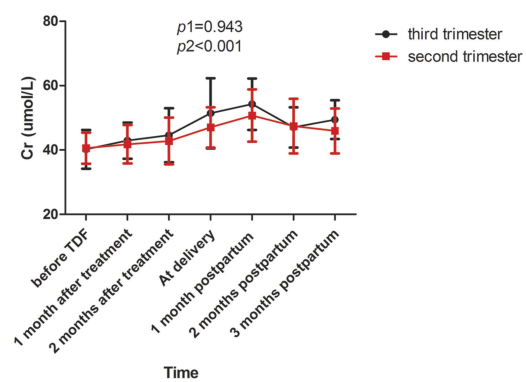

Figure 4 The dynamic changes of safety indicators: ALT (A), AST (B), ALB (C), HB (D), BUN (E), Cr (F).

Notes: $p l$ was calculated to test whether the effect of the group (sencond trimester vs third trimester) is significant in the mixed linear model. $p 2$ was calculated to test whether the effect of follow-up time is significant in the mixed linear model.

Abbreviations: AST, aspartate aminotransferase; ALT, alanine aminotransferase; ALB, albumin; HB, haemoglobin; BUN, blood urea nitrogen; Cr, creatinine.

Secondly, patients in the second trimester and third trimester groups successfully decreased HBV MTCT. The infection rates in infants were $0 \%$ in both groups. The two groups had a similar variation trend in HBV DNA and other HBV serologic markers from baseline to 3 months postpartum. Lastly, no evident deleterious events were observed in both groups; however, the decline in HB was more obvious during pregnancy when TDF treatment was started in the second trimester than that in the third trimester.

A recent meta-analysis demonstrated that lamivudine and telbivudine have better antiviral effects when administered from the second trimester than that from the third trimester. ${ }^{4}$ Few studies compare the differences in efficacy and safety of TDF treatment from different initiated trimesters. Only one study observed that starting TDF therapy from 24 weeks showed a more rapid viral decline than from 28 weeks of gestation $(p<0.001)$ in HBV-infected mothers resistant to lamivudine. ${ }^{29}$ However, this study did not investigate whether TDF treatment from the second trimester could achieve a better effect in pregnant women without a drug-resistant history. In our study, we provided a more comprehensive evaluation regarding efficacy and safety issues by comparing TDF treatment from the second and third trimesters in highly viraemic pregnant women (HBV DNA $>2 \times 10^{6} \mathrm{IU} / \mathrm{mL}$ ) without previous antiviral treatment.
Before this, Pan, in an RCT, observed that the reduction in HBV DNA from baseline to delivery was $3.56(3.02-4.32)$ $\log 10 \mathrm{IU} / \mathrm{mL}$ in patients who received TDF treatment from 30-32 weeks of gestation until postpartum week $4 .^{21}$ The pregnant women from Chen's study started TDF from gestational weeks 30-32 until 1 month postpartum. ${ }^{20}$ They discovered that the reduction in HBV DNA (baseline-delivery) was $3.89 \pm 0.87 \log 10 \mathrm{IU} / \mathrm{mL}^{20}$ Similarly, in a trial by Greenup, the mean reduction in HBV DNA was $3.64 \pm 0.9$ $\log 10 \mathrm{IU} / \mathrm{mL}$ (baseline-delivery) in pregnant women who started TDF treatment at 32 weeks of gestation and discontinued at 12 weeks postpartum. ${ }^{24}$ In our study, the reductions of HBV DNA (baseline-delivery) were $4.8 \pm 1.2 \log 10 \mathrm{IU} / \mathrm{mL}$ in patients who started the TDF treatment from the second trimester (24-27 weeks) and $4.3 \pm 1.1 \log 10 \mathrm{IU} / \mathrm{mL}$ in the third trimester group (28-30 weeks). None of the infants in our study were infected with HBV. The better antiviral effect we achieved can be attributed to the earlier starting time we used than that by other investigators. Although the best duration of antiviral treatment and initiation time are unknown, our study suggests that it is better to start TDF treatment from 24 weeks and no later than 27 weeks of gestation until 1 month postpartum, which could achieve comparatively effective results, as indicated by HBV DNA. Regarding safety issues, TDF treatment from the second 
Table 3 Maternal Adverse Events Of Pregnant Women Who Initiated TDF Therapy From The 2nd Trimester And The 3rd Trimester

\begin{tabular}{|c|c|c|c|}
\hline Events & $\begin{array}{l}\text { TDF } \\
\text { Treatment } \\
\text { From The } \\
\text { 2nd } \\
\text { Trimester } \\
\mathrm{n}=80\end{array}$ & $\begin{array}{l}\text { TDF } \\
\text { Treatment } \\
\text { From The } \\
\text { 2nd } \\
\text { Trimester } \\
\text { n=49 }\end{array}$ & $p$ \\
\hline $\begin{array}{l}\text { Maternal complications, } \mathbf{n}(\%) \\
\text { Intrahepatic cholestasis of } \\
\text { pregnancy }\end{array}$ & $2(2.5)$ & $3(6.1)$ & 0.300 \\
\hline Pregnancy-induced hypertension & $5(6.3 \%)$ & I (2\%) & 0.270 \\
\hline Fetal distress & $20(25)$ & $14(28.6)$ & 0.654 \\
\hline $\begin{array}{l}\text { Pregnancy-induced diabetes } \\
\text { mellitus }\end{array}$ & $\mathrm{I}(\mathrm{I} .3)$ & $0(0)$ & I \\
\hline FGR & $\mathrm{I}(\mathrm{I} .3)$ & $0(0)$ & I \\
\hline Macrosomia & $0(0)$ & $I(2)$ & 0.199 \\
\hline Preterm delivery & $\mathrm{I}(\mathrm{I} .3)$ & I (2) & 0.724 \\
\hline Breech delivery & $4(5)$ & $3(6.1)$ & 0.784 \\
\hline Placental abruption & $4(5)$ & $0(0)$ & 0.112 \\
\hline Cord around the infant's neck & $19(23.8)$ & $9(18.4)$ & 0.472 \\
\hline Postpartum hemorrhage & $0(0)$ & $0(0)$ & NA \\
\hline $\begin{array}{l}\text { Laboratory abnormality } \\
\text { Grade I or } 2, n(\%)\end{array}$ & & & \\
\hline $\begin{array}{l}\text { ALT level I.I-5 ULN } \\
\text { Anemia }\end{array}$ & $\begin{array}{l}38(47.5) \\
16(20.0)\end{array}$ & $\begin{array}{l}22(44.9) \\
7(14.3)\end{array}$ & $\begin{array}{l}0.774 \\
0.331\end{array}$ \\
\hline $\begin{array}{l}\text { Grade } 3 \text { or } 4, \mathrm{n}(\%) \\
\text { Increase of } \mathrm{Cr} \geq 0.5 \mathrm{mg} / \mathrm{dl} \text { from } \\
\text { baseline }\end{array}$ & $0(0)$ & $0(0)$ & NA \\
\hline Severe ALT flare & $3(3.8)$ & $\mathrm{I}(2)$ & 0.586 \\
\hline Serious ALT flare & $2(2.5)$ & $2(4.1)$ & 0.606 \\
\hline ALT flare, $n(\%)$ & & & \\
\hline $\begin{array}{l}\text { At any time point during the } \\
\text { follow-up period }\end{array}$ & $5(6.2)$ & $3(6.1)$ & 0.991 \\
\hline Baseline-delivery & $\mathrm{I}(\mathrm{I} .3)$ & $0(0)$ & 1 \\
\hline Postpartum period & $4(5)$ & $3(6.1)$ & 0.784 \\
\hline Peak ALT value (IU/L),mean \pm sd & $313.6 \pm 119.0$ & $378.0 \pm 112.6$ & 0.479 \\
\hline
\end{tabular}

Abbreviations: TDF, tenofovir disoproxil fumarate; FGR, fetal growth restriction; ALT, alanine aminotransferase; ULN, upper limit of normal; $\mathrm{Cr}$, creatinine; NA, not available.

trimester did not increase additional risk, unlike TDF treatment in the third trimester. However, we discovered that TDF led to a decline in $\mathrm{HB}$ concentration, especially in the second trimester group, and HB level returned to normal after delivery. Another important discovery from our study was that HBV DNA level before treatment was positively correlated with the decline degree of HBV DNA. One conceivable explanation is that TDF is a nucleotide reverse transcriptase inhibitor that prevents the virus from replicating and stops the swift growth of the virus. Therefore, patients with a higher viral load are more sensitive to TDF treatment.
Table 4 Factors Associated With The Decline In HBV DNA From TDF Initiation To Delivery By Multiple Linear Regression Analysis

\begin{tabular}{|l|l|l|l|}
\hline Variables & $\boldsymbol{\beta}$ & $\mathbf{9 5 \%} \mathbf{C I}$ & $\boldsymbol{P}$ \\
\hline Age (y) & 0.02 & $-0.0 \mathrm{I}$ to 0.05 & 0.215 \\
\hline Family history of hepatitis B & -0.13 & -0.42 to 0.16 & 0.375 \\
\hline $\begin{array}{l}\text { Second trimester vs third } \\
\text { trimester }\end{array}$ & 0.5 & 0.26 to 0.75 & $<0.00 \mathrm{I}$ \\
\hline HBV DNA-log 10 (IU/mL) & 0.92 & 0.78 to I.07 & $<0.00 \mathrm{I}$ \\
\hline HBsAg (IU/mL) & -0.0004 & -0.004 to 0.004 & 0.809 \\
\hline HBeAg (s/co) & -0.02 & -0.19 to 0.15 & 0.777 \\
\hline ALT (IU/L) & -0.01 & -0.02 to 0.001 & 0.076 \\
\hline HB (g/L) & 0.008 & -0.01 to 0.02 & 0.241 \\
\hline Caesarean section & -0.21 & -0.44 to 0.03 & $0.08 \mathrm{I}$ \\
\hline $\begin{array}{l}\text { Education (College and } \\
\text { above vs below college) }\end{array}$ & -0.07 & -0.34 to 0.21 & 0.628 \\
\hline Domicile (City vs Rural) & -0.02 & -0.30 to 0.25 & 0.870 \\
\hline $\begin{array}{l}\text { Number of pregnancy before } \\
\text { this delivery }\end{array}$ & -0.08 & -0.21 to 0.04 & 0.186 \\
\hline $\begin{array}{l}\text { Number of delivery before } \\
\text { this delivery }\end{array}$ & 0.05 & -0.23 to 0.35 & 0.713 \\
\hline
\end{tabular}

Abbreviations: $\beta$, regression coefficient; $\mathrm{Cl}$, confidence interval; HBV-DNA, hepatitis $B$ virus deoxyribonucleic acid; $\mathrm{HBsAg}$, hepatitis $B$ surface antigen; $\mathrm{HBeAg}$, hepatitis $B e$ antigen; ALT, alanine aminotransferase; $H B$, hemoglobin.

There are inevitable limitations in our study. Firstly, because of the limited sample size in our study, some differences may not have been observed between the two groups, such as HBsAg and $\mathrm{HBeAg}$ levels between the two groups and mean DNA level during the follow-up period between the two groups. However, we discovered that the reduction in HBV DNA was more rapid with TDF treatment from the second trimester than from the third trimester. Secondly, we did not stratify patients based on HBV DNA or HBsAg level for an earlier initiation because of the relatively small number of patients in the groups. Thirdly, there was a short follow-up duration in the study. Finally, adverse events, especially the long-term deleterious effects in infants when mothers started TDF from the second trimester, need to be observed in a future study.

\section{Conclusion}

This study showed that starting TDF treatment from the second trimester (24-27 weeks) may achieve better viral 
suppression than TDF treatment from the third trimester in highly viraemic pregnant women without increasing additional adverse reactions. HB level may decline during treatment and needs frequent monitoring during the TDF treatment period, especially in patients who received TDF from the second trimester. Our discoveries warrant additional research with an enlarged sample, particularly in RCTs, to assess the optimal initiation time of TDF treatment.

\section{Data Availability}

No further data will be shared and we will continue this research.

\section{Acknowledgments}

This study was funded by the National Natural Science Fund, China (81771615), Shaanxi Science and Technology Coordination Innovation Project Plan, China (2016KTCL0301), the Clinical Research Award of the First Affiliated Hospital of Xi'an Jiaotong University, China (XJTU1AFCRF-2018-008) and Shaanxi Key Science and Technology Innovation Team Project (2019TD-031).

\section{Disclosure}

The authors report no conflicts of interest in this work.

\section{References}

1. Jourdain G, Ngo-Giang-Huong N, Harrison L, et al. Tenofovir versus placebo to prevent perinatal transmission of hepatitis B. N Engl J Med. 2018;378(10):911-923. doi:10.1056/NEJMoa1708131

2. Cressey TR, Harrison L, Achalapong J, et al. Tenofovir exposure during pregnancy and postpartum in women receiving tenofovir disoproxil fumarate for the prevention of mother-to-child transmission of hepatitis B virus. Antimicrob Agents Chemother. 2018;62(12). doi:10.1128/AAC.01686-18

3. Jonas MM. Hepatitis B and pregnancy: an underestimated issue. Liver Int. 2009;29:133-139.

4. Song J, Yang F, Wang S, et al. Efficacy and safety of antiviral treatment on blocking the mother-to-child transmission of hepatitis B virus: A meta-analysis. $J$ Viral Hepat. 2019;26(3):397-406.

5. Jourdain G, Ngo-Giang-Huong N, Cressey TR, et al. Prevention of mother-to-child transmission of hepatitis B virus: a phase III, placebocontrolled, double-blind, randomized clinical trial to assess the efficacy and safety of a short course of tenofovir disoproxil fumarate in women with hepatitis B virus e-antigen. BMC Infect Dis. 2016;16:393.

6. Brown RS, McMahon BJ, Lok ASF, et al. Antiviral therapy in chronic hepatitis B viral infection during pregnancy: a systematic review and meta-analysis. Hepatology. 2016;63(1):319-333.

7. Dionne-Odom J, Tita AT, Silverman NS; Society for Maternal-Fetal M. \#38: hepatitis B in pregnancy screening, treatment, and prevention of vertical transmission. Am J Obstet Gynecol. 2016;214(1):6-14.

8. Beasley RP. Hepatitis-B virus - the major etiology of hepatocellularcarcinoma. Cancer. 1988;61(10):1942-1956.

9. Lavanchy D. Hepatitis B virus epidemiology, disease burden, treatment, and current and emerging prevention and control measures. $J$ Viral Hepat. 2004;11(2):97-107.
10. Wang M, Bian Q, Zhu Y, et al. Real-world study of tenofovir disoproxil fumarate to prevent hepatitis B transmission in mothers with high viral load. Aliment Pharmacol Ther. 2019;49(2):211-217. doi:10.1111/apt.15064

11. Hyun MH, Lee YS, Kim JH, et al. Systematic review with metaanalysis: the efficacy and safety of tenofovir to prevent mother-tochild transmission of hepatitis B virus. Aliment Pharmacol Ther. 2017;45(12):1493-1505. doi:10.1111/apt.14068

12. Cui F, Woodring J, Chan P, Xu F. Considerations of antiviral treatment to interrupt mother-to-child transmission of hepatitis B virus in China. Int $J$ Epidemiol. 2018;47(5):1529-1537. doi:10.1093/ije/dyy077

13. Papatheodoridis G, Buti M, Cornberg M, et al. EASL clinical practice guidelines: management of chronic hepatitis B virus infection. $J$ Hepatol. 2012;57(1):167-185.

14. Rapicetta M. New perspectives and models for hepatitis B vaccines and immunization. Vaccine. 2008;27(25):3271-3275. doi:10.1016/j. vaccine.2009.01.063

15. Marcellin P, Heathcote EJ, Buti M, et al. Tenofovir disoproxil fumarate versus adefovir dipivoxil for chronic hepatitis B. $N$ Engl J Med. 2008;359(23):2442-2455. doi:10.1056/NEJMoa0802878

16. Terrault NA, Lok ASF, McMahon BJ, et al. Update on prevention, diagnosis, and treatment of chronic hepatitis B: AASLD 2018 hepatitis B guidance. Hepatology. 2018;67(4):1560-1599.

17. Terrault NA, Bzowej NH, Chang KM, Hwang JP, Jonas MM, Murad MH. AASLD guidelines for treatment of chronic hepatitis B. Hepatology. 2016;63(1):261-283. doi:10.1002/hep.28156

18. World Health Organization. Guidelines for the Prevention, Care and Treatment of Persons with Chronic Hepatitis B Infection. Geneva: World Health Organization; 2015.

19. Korean Association for the Study of the L. KASL clinical practice guidelines: management of chronic hepatitis B. Clin Mol Hepatol. 2016;22(1):18-75. doi:10.3350/cmh.2016.22.1.18

20. Chen HL, Lee CN, Chang $\mathrm{CH}$, et al. Efficacy of maternal tenofovir disoproxil fumarate in interrupting mother-to-infant transmission of hepatitis B virus. Hepatology. 2015;62(2):375-386. doi:10.1002/ hep. 27837

21. Pan CQ, Duan Z, Dai E, et al. Tenofovir to prevent hepatitis B transmission in mothers with high viral load. $N$ Engl $J$ Med. 2016;374(24):2324-2334. doi:10.1056/NEJMoa1508660

22. Brown RS Jr., McMahon BJ, Lok AS, et al. Antiviral therapy in chronic hepatitis B viral infection during pregnancy: A systematic review and meta-analysis. Hepatology. 2016;63(1):319-333. doi:10.1002/hep.28302

23. Fan R, Yin XR, Hou JL. Prevention of peripartum hepatitis B transmission. $N$ Engl J Med. 2016;375(15):1496-1498. doi:10.1056/ NEJMc1609991

24. Greenup AJ, Tan PK, Nguyen V, et al. Efficacy and safety of tenofovir disoproxil fumarate in pregnancy to prevent perinatal transmission of hepatitis B virus. J Hepatol. 2014;61(3):502-507.

25. Zhang H, Pan CQ, Pang Q, Tian R, Yan M, Liu X. Telbivudine or lamivudine use in late pregnancy safely reduces perinatal transmission of hepatitis B virus in real-life practice. Hepatology. 2014. doi:10.1002/hep.27034

26. Yi W, Pan CQ, Li MH, et al. The characteristics and predictors of postpartum hepatitis flares in women with chronic hepatitis B. Am J Gastroenterol. 2018;113(5):686-693. doi:10.1038/s41395-018-0010-2

27. Kochaksaraei GS, Castillo E, Osman M, et al. Clinical course of 161 untreated and tenofovir-treated chronic hepatitis B pregnant patients in a low hepatitis B virus endemic region. J Viral Hepat. 2016;23 (1):15-22. doi:10.1111/jvh.2015.23.issue-1

28. Nguyen V, Tan PK, Greenup AJ, et al. Anti-viral therapy for prevention of perinatal HBV transmission: extending therapy beyond birth does not protect against post-partum flare. Aliment Pharmacol Ther. 2014;39(10):1225-1234. doi:10.1111/apt.12726

29. Wang J, Liu J, Qi C, et al. Efficacy of tenofovir disoproxil fumarate to prevent vertical transmission in mothers with lamivudine-resistant HBV. Antivir Ther. 2015;20(7):681-687. doi:10.3851/IMP2981 


\section{Publish your work in this journal}

Infection and Drug Resistance is an international, peer-reviewed openaccess journal that focuses on the optimal treatment of infection (bacterial, fungal and viral) and the development and institution of preventive strategies to minimize the development and spread of resistance. The journal is specifically concerned with the epidemiology of antibiotic resistance and the mechanisms of resistance development and diffusion in both hospitals and the community. The manuscript management system is completely online and includes a very quick and fair peerreview system, which is all easy to use. Visit http://www.dovepress.com/ testimonials.php to read real quotes from published authors. 